\title{
Butterflies (Lepidoptera: Papilionoidea) from the campos rupestres of Serra de São José, Minas Gerais, Brazil
}

\author{
Nathália Ribeiro Henriques $^{I^{*} \mathbb{D}}$, Marina do Vale Beirão ${ }^{2}$, Ello Brasil ${ }^{2}$ \& Tatiana Cornelissen ${ }^{1}$ \\ ${ }^{1}$ Universidade Federal de São João del Rei, Departamento de Ciências Naturais, Programa de Pós-Graduação \\ em Ecologia, São João del-Rei, MG, Brasil \\ ${ }^{2}$ Universidade Federal de Ouro Preto, Departamento de Biologia Geral, Programa de Pós-Graduação em \\ Ecologia de Biomas Tropicais, Ouro Preto, MG, Brasil \\ *Corresponding author: Nathália Ribeiro Henriques, e-mail: h.nathaliaribeiro@gmail.com
}

HENRIQUES, N. R., BEIRÃO, M. V., BRASIL, E., CORNELISSEN, T. Butterflies (Lepidoptera: Papilionoidea) from the campos rupestres of Serra de São José, Minas Gerais, Brazil. Biota Neotropica. 19(3): e20180655. http://dx.doi.org/10.1590/1676-0611-BN-2018-0655

\begin{abstract}
We provide the first inventory of butterfly species (Lepidoptera: Papilionoidea) in Serra de São José, Minas Gerais, Brazil. Serra de São José has elevations ranging from $800 \mathrm{~m}$ to 1,400 m above sea level; the butterflies were sampled using traps and entomological nets in seven plots along the altitudinal gradient. We recorded 647 butterflies belonging to 112 species and six families. We also recorded one threatened species and three endemic species for the Cerrado domain, which suggests that Serra de São José is an important refuge for butterfly conservation. Keywords: Cerrado, Conservation, Diversity, Inventory, Species richness, Threatened species.
\end{abstract}

\section{Borboletas (Lepidoptera: Papilionoidea) dos campos rupestres da Serra de São José, Minas Gerais, Brasil}

Resumo: Fornecemos o primeiro levantamento de espécies de borboletas (Lepidoptera: Papilionoidea) da Serra de São José, Minas Gerais, Brazil. A Serra de São José possui elevações variando de 800 a 1.400 m de altitude, onde as borboletas foram amostradas utilizando armadilhas e redes entomológicas em sete áreas ao longo do gradiente altitudinal. Nós registramos 647 borboletas pertencentes a 112 espécies e seis famílias. Também registramos uma espécie ameaçada e três espécies endêmicas do Cerrado, o que sugere que a Serra de São José seja um importante refúgio para a conservação de borboletas.

Palavras-chave: Cerrado, Conservação, Diversidade, Levantamento, Riqueza de espécies, Espécies ameaçadas.

\section{Introduction}

Campos rupestres is a type of vegetation in high-altitude environments that covers rocky outcrops and is found most often in quartzite soil (Fernandes 2016). It occupies about $0.78 \%$ of the area in Brazil and its core area is along the Espinhaço Range (Silveira et al. 2016). Campos rupestres are recognized for their great biodiversity; their most striking aspects are the large number of endemic flora and fauna species they contain (Rapini et al. 2008, Fernandes et al. 2014). There is very little information about many insect groups, including butterflies, in several regions of Brazil (Freitas \& Marini-Filho 2011, Soldati et al. 2019), and lepidopteran studies of campos rupestres remain scarce.

Brazil hosts more than 3,000 butterfly species, about $40 \%$ of the known richness of Neotropical butterflies - almost 8,000 species (Lamas 2008, CTFB 2018). Butterflies represent about 13\% of Lepidoptera (Heppner 1991) and are separated into two large guilds according to feeding habits as adults: the frugivorous butterflies can feed on fruits, exudates, and plant sap and include more than $50 \%$ of Nymphalidae, whereas nectarivorous butterflies feed on nectar and are found in all families, including some species of Nymphalidae (DeVries et al. 1997). Their colors and shapes make them a charismatic group, attracting researchers and sensitizing the population to environmental conservation, and they can also be used as flagship species for ecosystem protection and biodiversity conservation plans (Guiney \& Oberhauser 2008, Santos et al. 2011).

Butterflies are considered a suitable bioindicator taxa (Thomas 2005), as they have a short lifespan, can be easily sampled, and are sensitive to climatic variations, responding quickly to environmental changes (Freitas et al. 2003, Uehara-Prado et al. 2009, Francini et al. 2011). Moreover, several butterfly species are listed as endangered (IUCN 2016), and many species are considered rare, with only one (singleton) or two (doubleton) individuals sampled (Cowell 2004, Ferraz et al. 2009). Knowledge of local diversity is a fundamental ecological issue (Nobre et al. 2008), and species lists constructed with precise identification of organisms can be valuable for future studies. A species list can therefore aid the creation of conservation units and protected areas (Bustos 2008, Mielke et al. 2008) and provide basic data on distribution, abundance, and occurrence. 
Biodiversity knowledge is the first step for formulating policies for preserving butterfly communities and for generating data to support future research (Dolibaina et al. 2011). Although species survey is encouraged, research on butterfly communities at altitudinal gradients and tropical mountains remains insufficient (Pires et al. 2018 and references therein), especially in campos rupestres. For the Campo das Vertentes mesoregion, where the Environmental Protection Area of Serra de São José is located in Minas Gerais state, data on the butterfly fauna remain nonexistent. Considering the lack of studies in the entire region, the aim of the present study was to provide the first list of butterfly species of the campos rupestres of Serra de São José, Minas Gerais, Brazil.

\section{Material and Methods}

\section{Study area}

The study was conducted inside Environmental Protection Area of Serra de São José, located in south-central Minas Gerais $\left(21^{\circ}\right.$ 7' $8.87^{\prime}$ S, $44^{\circ}$ 7' 22.84" W, Figure 1). It belongs to the Serra da Mantiqueira system, but its vegetation and geological characteristics are quite similar to that of the Espinhaço Range (Oliveira-Filho \& Machado 1993, Vasconcelos 2011). Serra de São José has elevations ranging from $800 \mathrm{~m}$ to $1,400 \mathrm{~m}$ above sea level, and exhibits phytophysiognomies of the Cerrado and Atlantic domains, with semideciduous seasonal forest and cerrado at its lower elevations, and campos rupestres at the highest elevations. It spans 4,758 ha (Cirino $\&$ Lima 2008) and the climate is marked by mild summers and winter droughts (Köppen classification: Cwb; Alvares et al. 2013). The average annual rainfall is about $1,500 \mathrm{~mm}$; the average temperature ranges $19-20^{\circ} \mathrm{C}$ (Gonzaga et al. 2008).

\section{Data sampling}

Butterfly sampling was performed over a 1-year period (March 2016 to March 2017) over four seasons (Season 1: March and April 2016, Season 2: June and July 2016, Season 3: November and December 2016, Season 4: January, February, and March 2017) along seven altitudinal bands between $800 \mathrm{~m}$ and 1,413 m, with sampling at every $100 \mathrm{~m}$ of altitude. Van Someren-Rydon traps, separated by at least $50 \mathrm{~m}$, were placed at all altitudinal bands to capture frugivorous butterflies. The traps remained in the field for 72 hours and were baited with a mixture of banana and molasses that had been fermented for 48 hours (Uehara-Prado et al. 2009, Santos et al. 2011). The trap effort totaled 864 hours. Net sampling was also performed at each altitudinal band during the same 1-year period, when the butterflies are most active, i.e., in the mornings and early afternoons (9 a.m. to 3 p.m., Santos et al. 2011, Silva et al. 2017). At each altitudinal band, net sampling was carried out for nearly five hours per day, totaling 155 effective hours in 28 sampling periods. The sampled butterflies were placed in entomological envelopes with descriptions of the altitude, and the date and time of collection. The butterflies were sacrificed, mounted, and later identified with the aid of field guides and/or specialists. The butterflies were organized into a reference collection deposited at the Entomological Collection of the Department of Natural Sciences of the Federal University of São João del-Rei (DCNat/UFSJ).
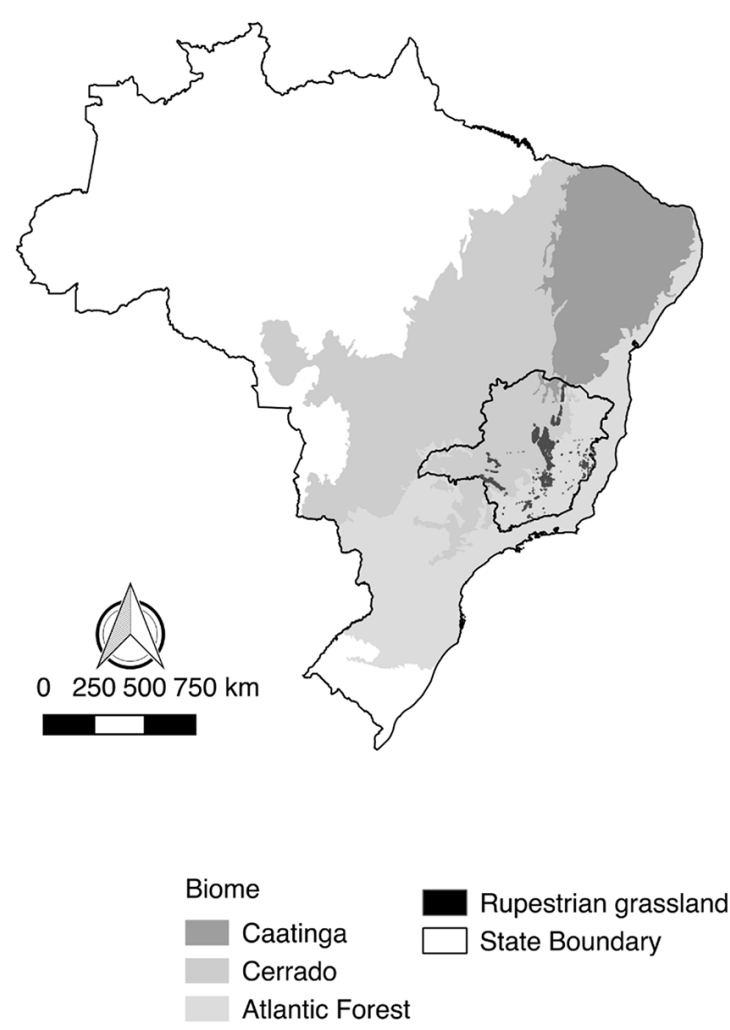

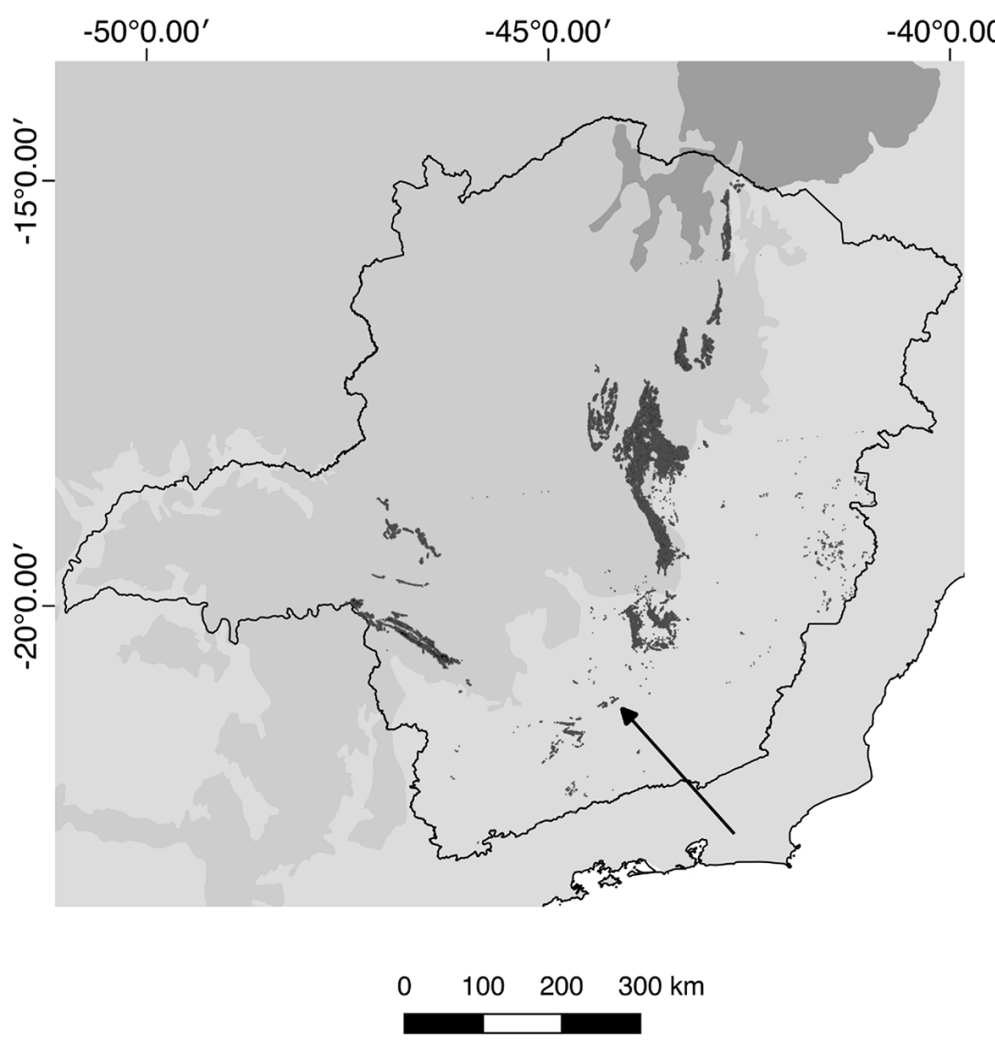

Figure 1. Map of the location of Serra de São José, Minas Gerais, Brazil. 


\section{Data analysis}

To evaluate sampling efficiency, a rarefaction curve was built using the specaccum function in Vegan (Oksanen et al. 2015) in R software (R Core Team 2017); the rarefaction method was based on the sampling periods ( 7 bands $\times 4$ seasons). To estimate butterfly diversity, three richness estimator indices (Jackknife 1, Chao 1, Bootstrap) were calculated using the specpool function in Vegan. Additionally, rare species were classified as singleton (one individual sampled) or doubleton (two individuals sampled) (Ferraz et al. 2009) to examine the species distribution frequency in the butterfly community.

\section{Results}

A total of 647 individual butterflies from 112 species belonging to 19 subfamilies were recorded in the campos rupestres of Serra de São José (Table 1). Nymphalidae (67 species, 58.04\% of all species sampled) was the most speciose family, followed by Hesperiidae (18 species, 16.07\%), Pieridae (11 species, 9.82\%), Lycaenidae (7 species, 6.25\%), Riodinidae (6 species, 5.36\%), and Papilionidae (5 species, 4.46\%). Nymphalidae was also the most abundant family, comprising more than $50 \%$ of all specimens sampled (327 individuals, $50.5 \%$ of the total recorded), followed by Hesperiidae $(\mathrm{N}=140,21.6 \%)$, Pieridae $(\mathrm{N}=116,17.9 \%)$, Lycaenidae $(\mathrm{N}=39$, $6.0 \%)$, Papilionidae $(\mathrm{N}=16,2.5 \%)$, and Riodinidae $(\mathrm{N}=11,1.7 \%)$. The most abundant species were Pyrisitia nise tenella (Pieridae: Coliadinae, $\mathrm{N}=46$ ), Urbanus teleus (Hesperiidae: Eudaminae, $\mathrm{N}=$ 44), Actinote thalia pyrrha (Nymphalidae: Heliconiinae, $\mathrm{N}=36$ ), and Pharneuptychia pharnabazos (Nymphalidae: Satyrinae, $\mathrm{N}=$ 27). Together, these four species represented $24 \%$ of all butterflies sampled. Only two species occurred at all seven altitudinal bands: Actinote genitrix genitrix (Nymphalidae: Heliconiinae) and Pyrisitia nise tenella (Pieridae: Coliadinae). We found three endemic Cerrado species (following Pinheiro et al. 2010): Parides bunichus diodorus (Papilionidae: Papilioninae), Sophista latifasciata latifasciata (Hesperiidae: Pyrginae), and Yphthimoides straminea (Nymphalidae: Satyrinae), and we registered one species listed in the Brazilian Red List: Actinote zikani (Nymphalidae: Heliconiinae).

Despite our sampling efforts, the species-rarefaction curve did not reveal any asymptote tendency (Figure 2). Jackknife 1 predicted that there would be 155 species, i.e., 43 species additional to those sampled in this study; Chao 1 and Bootstrap estimated 156 and 132 species, respectively. Of the 327 butterflies recorded for Nymphalidae, only 37 individuals were sampled in traps, and five species were caught exclusively in traps: Callicore sorana sorana (Biblidinae), Caligo brasiliensis brasiliensis (Satyrinae), Fountainea ryphea phidile (Charaxinae), Taygetis laches (Satyrinae), and Temenis laothoe meridionalis (Biblidinae). We recorded 36 species with only a single individual (singletons) and 21 species with only two individuals (doubletons), indicating that half of the sampled butterfly species are rare.

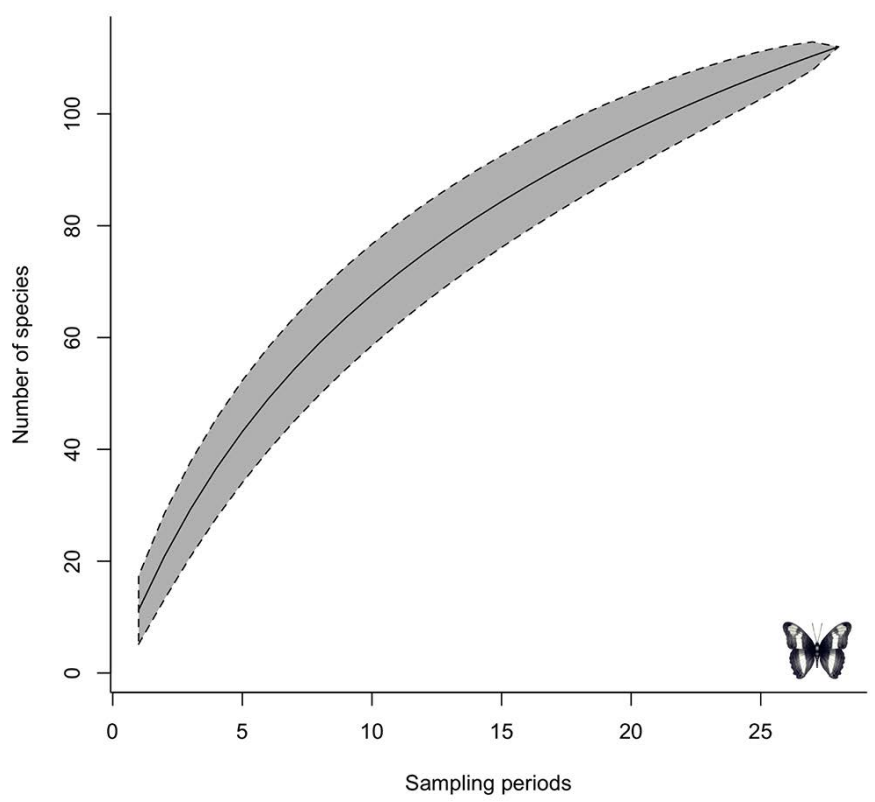

Figure 2. Rarefaction curve based on sampling period of butterfly species in Serra de São José, Minas Gerais, Brazil. Error bars indicate 95\% confidence intervals.

\section{Discussion}

The richness of butterfly species on Serra de São José is within the expected range for the campos rupestres, although it is higher than that observed in other inventories for the Brazilian Cerrado and open grassy vegetation (e.g., Bogiani et al. 2012, Araújo \& Paprocki 2015, Fernandes et al. 2016, Martins et al. 2017). For example, Nery et al. (2014) used the same two sampling methods and found 60 species in Serra do Intendente, Minas Gerais — a 13.447 ha area — which is much larger than Serra de São José. Pires et al. (2018) found 172 species in Serra do Cipó, Minas Gerais, an area similar in altitude and vegetation type to Serra de São José, but a much greater area (almost 34.000 ha) and with greater sampling effort (the present study versus Pires et al. 2018: net, 155 hours versus 336 hours; bait trap, 36 days versus 252 days).

Comparing the present species list to that of Nery et al. (2014) and Pires et al. (2018), the two closest mountain regions to Serra de São José with published inventories, we found 20 shared species with Serra do Intendente (Nery et al. 2014) and 39 shared species with Serra do Cipó (Pires et al. 2018). In addition, 16 species are found in all three mountains (Table 1). The large number of species shared with Serra do Cipó was expected due to the greater number of species listed and because it is a campos rupestres area (sensu Silveira et al. 2016) extremely similar to Serra de São José. Despite this, there was only $23 \%$ shared species, demonstrating that several butterfly species are exclusive to each region.

Even in small habitats, it is extremely difficult to estimate the total richness of organisms, especially in the case of insects, a megadiverse group (Beutel et al. 2017). According to the Jackknife 1 estimator, $72.3 \%$ of the species pool was sampled at Serra de São José, higher compared to the $66-68 \%$ found by Pereira et al. (2017) 
HENRIQUES, N. R. et al.

Table 1. List of butterfly species from Serra de São José, Minas Gerais, Brazil. S = number of species; * = shared species with Serra do Intendente, Minas Gerais (Nery et al. 2014); $\bullet=$ shared species with Serra do Cipó, Minas Gerais (Pires et al. 2018).

\begin{tabular}{|c|c|}
\hline Species & Abundance \\
\hline \multicolumn{2}{|l|}{ HESPERIIDAE (S = 18) } \\
\hline \multicolumn{2}{|l|}{ Eudaminae $(S=4)$} \\
\hline Urbanus evenus (Ménetriés, 1855) • & 2 \\
\hline Urbanus proteus proteus (Linnaeus, 1758) & 14 \\
\hline \multicolumn{2}{|l|}{ Hesperiinae $(S=4)$} \\
\hline Argon lota (Hewitson, 1877) & 10 \\
\hline Hylephila phyleus phyleus (Drury, 1773)・ & 2 \\
\hline Polites vibex catilina (Plötz, 1886) • & 2 \\
\hline Vettius artona (Hewitson, 1868) & 3 \\
\hline \multicolumn{2}{|l|}{ Pyrginae $(S=10)$} \\
\hline Heliopetes arsalte arsalte (Linnaeus, 1758) • & 1 \\
\hline Heliopetes omrina (A. Butler, 1870)*• & 12 \\
\hline Pyrgus orcus (Stoll, 1780) *• & 14 \\
\hline Pyrgus orcynoides (Giacomelli, 1928) & 1 \\
\hline Sarbia damippe Mabille \& Boullet, 1908 & 2 \\
\hline Sophista latifasciata latifasciata (Spitz, 1930)・ & 1 \\
\hline Staphylus chlorocephala (Latreille, [1824]) & 6 \\
\hline Timochares trifasciata trifasciata (Hewitson, 1868) & 2 \\
\hline \multicolumn{2}{|l|}{ Polyommatinae ( $\mathrm{S}=2)$} \\
\hline Contrafacia imma (Prittwitz, 1865) & 1 \\
\hline Ministrymon cruenta (Gosse, 1880) & 1 \\
\hline Strymon mulucha (Hewitson, 1867) • & 2 \\
\hline Tmolus echion (Linnaeus, 1767) & 2 \\
\hline \multicolumn{2}{|l|}{ NYMPHALIDAE $(S=65)$} \\
\hline \multicolumn{2}{|l|}{ Biblidinae $(S=9)$} \\
\hline Callicore sorana sorana (Godart, [1824]) * • & 3 \\
\hline Dynamine agacles agacles (Dalman, 1823) & 1 \\
\hline Ectima thecla thecla (Fabricius, 1796) & 1 \\
\hline Hamadryas chloe rhea (Fruhstorfer, 1907) & 2 \\
\hline Hamadryas epinome (C. Felder \& R. Felder, 1867) & 1 \\
\hline Hamadryas februa februa (Hübner, [1823]) * • & 4 \\
\hline Hamadryas feronia feronia (Linnaeus, 1758) * • & 1 \\
\hline Temenis laothoe meridionalis Ebert, $1965 *$ & 1 \\
\hline Myscelia orsis (Drury, 1782) & 1 \\
\hline \multicolumn{2}{|l|}{ Charaxinae $(S=1)$} \\
\hline Fountainea ryphea phidile (Geyer, 1837) & 2 \\
\hline
\end{tabular}


Danainae ( $\mathbf{S}=\mathbf{8})$

Aeria olena olena Weymer, 1875

Danaus eresimus plexaure (Godart, 1819)

Episcada hymenaea hymenaea (Prittwitz, 1865)

Hypothyris euclea laphria (E. Doubleday, 1847)

Mcclungia cymo salonina (Hewitson, 1855)

Mechanitis polymnia casabranca Haensch, 1905

Methona themisto themisto (Hübner, 1818)

Pseudoscada erruca (Hewitson, 1855)

Heliconiinae $(\mathbf{S}=12)$

Actinote carycina Jordan, 1913

Actinote genitrix genitrix R.F. d'Almeida, 1922

Actinote melanisans Oberthür, 1917

Actinote surima surima (Schaus, 1902)

Actinote thalia pyrrha (Fabricius, 1775)

Actinote zikani R.F. d'Almeida, 1951

Agraulis vanillae maculosa (Stichel, [1908])

Dione juno juno (Cramer, 1779)

Dryas iulia alcionea (Cramer, 1779) *

Eueides pavana Ménétriés, 1857

Heliconius erato phyllis (Fabricius, 1775) * •

Heliconius ethilla narcaea (Godart, 1819) * •

Libytheinae ( $\mathbf{S}=\mathbf{1})$

Libytheana carinenta carinenta (Cramer, 1777)

Limenitidinae (S=3)

Adelpha abia (Hewitson, 1850)

3

Adelpha lycorias lycorias (Godart, [1824])

Adelpha syma (Godart, [1824])

Nymphalinae ( $\mathrm{S}=7)$

Anartia amathea roeselia (Eschscholtz, 1821) *

Anartia jatrophae jatrophae (Linnaeus, 1763) •

Eresia lansdorfi (Godart, 1819) * •

Historis odius dious Lamas, 1995

Junonia evarete evarete (Cramer, 1779) * •

Hermeuptychia sp.

Moneuptychia giffordi A.V.L. Freitas, Emery \& O.H.H. Mielke, 2010

Moneuptychia melchiades (A. Butler, 1877)

Morpho anaxibia (Esper, [1801]) 
continuation...

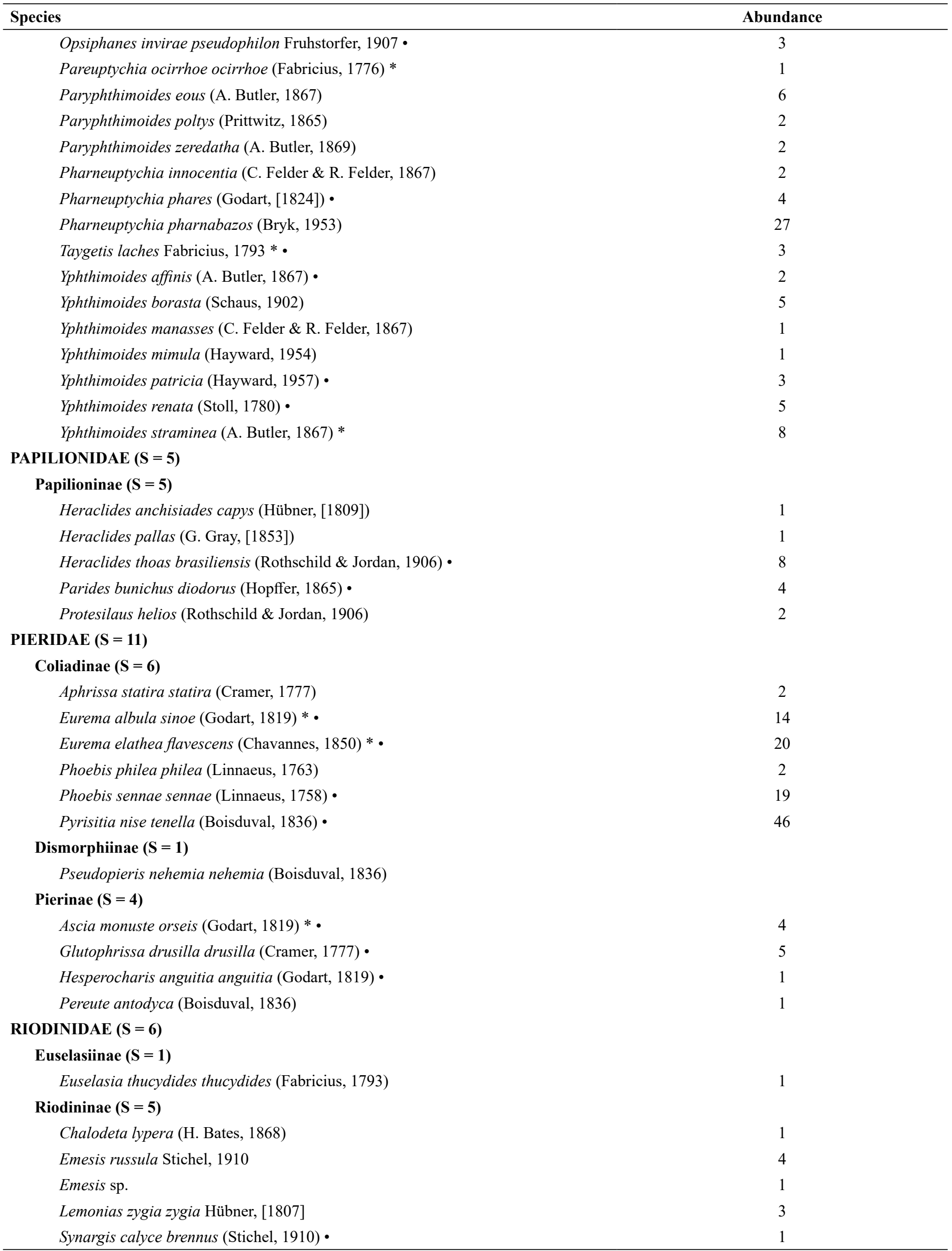


in Serra do Cipó and by Silva et al. (2015) in a Special Protection Area of Nova Lima (Minas Gerais), respectively. Bogiani et al. (2012) found $81 \%$ of the species estimated by Jackknife 1 in a Cerrado urban area, although only 60 species were recorded using the same two sampling methods and a very similar effort-hour to our study. The species richness estimated for Serra de São José indicates that the area, although smaller, might surpass the butterfly biodiversity of other campos rupestres areas.

Nymphalidae and Hesperiidae were the most represented families in our survey, a pattern already described and expected, as these two families, together with Lycaenidae, are among the families with the greatest species richness in Brazil (Bonfantti et al. 2009). In the present study, Nymphalidae exhibited the highest species richness and the greatest abundance. The family Nymphalidae has the greatest diversity of forms and behaviors and has nearly 800 species registered in Brazil (Silva et al. 2015, Ribeiro et al. 2016). Hesperiidae, in turn, is found in hilltops and open areas. It is very abundant in the high-altitude regions of southeastern Brazil, where many endemic species are found, and with high endemism in the Neotropical regions (Iserhard \& Romanowski 2004, Carneiro et al. 2014, Pires et al. 2018).

The International Union for Conservation of Nature (IUCN) Red List describes the species conservation status in several categories, and the threatened species are grouped into three categories: vulnerable, endangered, and critically endangered (IUCN 2016). One butterfly species recorded in Serra de São José is listed in the Brazilian Red List as critically endangered (CR), the highest risk category among the threatened species: Actinote zikani (Nymphalidae: Heliconiinae). Despite the difficulty in accurately identifying which species are endemic to certain habitats, Pinheiro et al. (2010) presented a list of endemic butterflies of the Cerrado domain. Three species found in Serra de São José appear in this list: Parides bunichus diodorus (Papilionidae: Papilioninae), Sophista latifasciata latifasciata (Hesperiidae: Pyrginae) and Yphthimoides straminea (Nymphalidae: Satyrinae). The conservation of these endangered and endemic species in this mountain can be important for their preservation at regional and/or national level.

The campos rupestres is a mountaintop vegetation occurring exclusively in Brazil that harbors a great biodiversity of both plants and animals. It is a very important area for conservation aiming to preserve the high number of endemic species and their populations (Alves et al. 2014, Silveira et al. 2016). The butterfly fauna of campos rupestres remain poorly documented. In the last few years, new butterfly species of campos rupestres have been described (e.g., Yphthimoides bella and $Y$. iserhardi in Barbosa et al. 2015, Nhambikuara cerradensis in Freitas et al. 2018), showing the importance of research in this habitat and thereby emphasizing the importance of campos rupestres for butterfly biodiversity. Our study reveals that the campos rupestres of Serra de São José exhibits a diverse butterfly community and we aim to contribute to the knowledge of high-altitude butterflies in the region and for tropical mountains of campos rupestres, thereby providing the first inventory for the region. The large number of rare species found in this mountain, together with the endemic and threatened species recorded, suggests that this is an important area for butterfly conservation, and it deserves attention.

\section{Acknowledgments}

We thank UFSJ and LEVIN for support. Nathália R. Henriques was supported by CAPES through a graduate scholarship and Tatiana Cornelissen acknowledges CNPq (grant \#307210/2016-2). We thank the reviewers for their effort and their comments that greatly improved the manuscript.

\section{Author contributions}

Nathália Ribeiro Henriques: Contribution in the concept and design of the study; Contribution to data collection; Contribution to butterfly identification; Contribution to data analysis and interpretation; Contribution to manuscript preparation; Contribution to critical revision.

Marina do Vale Beirão: Contribution to butterfly identification; Contribution to data analysis and interpretation; Contribution to manuscript preparation; Contribution to critical revision.

Ello Brasil: Contribution in the concept and design of the study; Contribution to data collection.

Tatiana Cornelissen: Contribution in the concept and design of the study; Contribution to manuscript preparation; Contribution to critical revision.

\section{Conflicts of interest}

The authors declare that they have no conflict of interest related to the publication of this manuscript.

\section{References}

Alvares C.A., Stape J.L., Sentelhas P.C., Moraes G., Leonardo J. \& Sparovek G. 2013. Köppen's climate classification map for Brazil. Meteorol. Z. 22(6): 711-728.

Alves R.J.V., Silva N.G., Oliveira J.A. \& Medeiros D. 2014. Circumscribing campo rupestre - megadiverse Brazilian rocky montane savanas. Braz. J. Biol. 74(2): 355-362.

Araújo M.C. \& Paprocki H. 2015. Lista de Lepidoptera do Parque Ecológico Felisberto Neves, Betim, Minas Gerais. Sinapse Múltipla 4(1): 1-15.

Barbosa E.P., Silva A.K., Paluch M., Azeredo-Espin A.M.L. \& Freitas A.V.L. 2015. Uncovering the hidden diversity of the Neotropical butterfly genus Yphthimoides Forster (Nymphalidae: Satyrinae): description of three new species based on morphological and molecular data. Org. Divers. Evol. 15(3): 577-589.

Beutel R.G., Yavorskaya M.I., Mashimo Y., Fukui M. \& Meusemann K. 2017. The phylogeny of Hexapoda (Arthropoda) and the evolution of megadiversity. Proc. Arthropod. Embryol. Soc. Jpn. 51: 1-15.

Bogiani P.A., Aranda R. \& Machado C.O.F. 2012. Riqueza de Borboletas (Lepidoptera) em um Fragmento Urbano de Cerrado em Mato Grosso do Sul, Brasil. EntomoBrasilis 5(2): 93-98.

Bonfantti D., Di Mare R.A. \& Giovenardi R. 2009. Butterflies (Lepidoptera: Papilionoidea and Hesperioidea) from two forest fragments in northern Rio Grande do Sul, Brazil. Check List 5(4): 819-829.

Bustos E.O.N. 2008. Diversidad de mariposas diurnas en la Reserva Privada Yacutinga, Provincia de Misiones, Argentina (Lepidoptera: Hespedioidea y Papilionoidea). Trop. lepid. res. 18(2): 78-87.

Carneiro E., Mielke O.H.H., Casagrande M.M. \& Fiedler K. 2014. Skipper Richness (Hesperiidae) Along Elevation Gradients in Brazilian Atlantic Forest. Neotrop. Entomol. 43(1): 27-38.

Cirino J.F. \& Lima J.E. 2008. Valoração contingente da Área de Proteção Ambiental (APA) São José - MG: um estudo de caso. Ver. Econ. Sociol. Rural 46(3): 647-672. 
Colwell R.K. 2004. User's guide to EstimateS5 statistical. Estimation of species richness and shared species from samples. Version 7.0.0. Copyright 19942004. http://viceroy.eeb.uconn.edu/estimates (last access on 07/12/2018).

CTFB - Catálogo Taxonômico da Fauna do Brasil. http://fauna.jbrj.gov.br (last access in 04/11/2018).

DeVries P.J., Murray D. \& Lande R. 1997. Species diversity in vertical, horizontal, and temporal dimensions of a fruit-feeding butterfly community in an Ecuadorian rainforest. Biol. J. Linnean Soc. 62(3): 343-364.

Dolibaina D.R., Mielke O.H.H. \& Casagrande M.M. 2011. Borboletas (Papilionoidea e Hesperioidea) de Guarapuava e arredores, Paraná, Brasil: um inventário com base em 63 anos de registros. Biota Neotrop. 11(1): 1-14 http://www.biotaneotropica.org.br/v11n1/en/abstract?inventory+ bn00211012011 (last access on 17/08/2018).

Fernandes G.W. 2016. The Megadiverse Rupestrian Grassland. In Ecology and Conservation of Mountaintop Grasslands in Brazil (G.W. Fernandes, ed.). Springer, São Paulo, p. 3-12.

Fernandes G.W., Almeida H.A., Nunes C.A., Xavier J.H.A., Cobb N.S., Carneiro M.A.A., Cornelissen T., Neves F.S., Ribeiro S.P., Nunes Y.R.F., Pires A.C.V. \& Beirão M.V. 2016. Cerrado to Rupestrian Grasslands: Patterns of Species Distribution and the Forces Shaping Them Along an Altitudinal Gradient. In Ecology and Conservation of Mountaintop Grasslands in Brazil (G.W. Fernandes, ed.). Springer, São Paulo, p. 345-377.

Fernandes G.W., Barbosa N.P.U., Negreiros D. \& Paglia A.P. 2014. Challenges for the conservation of vanishing megadiverse rupestrian grasslands. Nat. Conserv. 2(12): 162-165.

Ferraz A.C.P., Gadella B.Q. \& Aguiar-Coelho V.M. 2009. Análise faunística de Calliphoridae (Diptera) da Reserva Biológica do Tinguá, Nova Iguaçu, Rio de Janeiro. Rev. Bras. Entomol. 53: 620-628.

Francini R.B., Duarte M., Mielke O.H.H., Caldas A. \& Freitas A.V.L. 2011. Butterflies (Lepidoptera, Papilionoidea and Hesperioidea) of the "Baixada Santista" region, coastal São Paulo, southeastern Brazil. Rev. Bras. Entomol. 55(1): 55-68

Freitas A.V.L. \& Marini-Filho O.J. 2011. Plano de ação nacional para conservação dos lepidópteros ameaçados de extinção. ICMBio, Brasília, 124 p.

Freitas A.V.L., Barbosa E.P., Zacca T., Marín M.A., Beirão M.V., Silva A.R.M., Casagrande M.M., Espeland M. \& Willmott K.R. 2018. Before it is too late: description of a new genus and species of butterfly from a highly threatened Brazilian biome. Rev. Bras. Entomol. 62(2): 148-158.

Freitas A.V.L., Francini R.B. \& Brown, K.S. 2003. Insetos como indicadores ambientais. In Métodos de estudos em biologia da conservação e manejo da vida silvestre (L. Cullen, C. Valladares-Pádua \& R. Rudran, orgs.). Editora da UFPR, Paraná, p. 205-239.

Gonzaga A.P.D., Oliveira-Filho A.T., Machado E.L.M., Hargreaves P. \& Machado J.N.M. 2008. Diagnóstico florístico-estrutural do componente arbóreo da floresta da Serra de São José, Tiradentes, MG, Brasil. Acta bot. bras. 22(2): 505-520.

Guiney M.S. \& Oberhauser K.S. 2008. Insects as flagship conservation species. Terr. Arthropod Rev. 1(2): 111-123.

Heppner J.B. 1991. Faunal regions and the diversity of Lepidoptera. Tropical Lepidoptera 2(1): 1-85.

Iserhard C.A. \& Romanowski H.P. 2004. Lista de espécies de borboletas (Lepidoptera, Papilionoidea e Hesperioidea) da região do vale do rio Maquiné, Rio Grande do Sul, Brasil. Rev. Bras. Zool. 21(3): 649-662.

IUCN - International Union for Conservation of Nature. 2016. The IUCN Brazil Red Book of Threatened Species of Fauna. Realized by ICMBio and MMA.

Lamas G. 2008. La sistemática sobre mariposas (Lepidoptera: Hesperioidea y Papilionoidea) em el mundo: estado actual y perspectivas futuras. In Contribuciones taxonómicas em órdenes de insectos hiperdiversos (J.L. Bousquets \& A. Lanteri, eds.). Las Prensas de Ciencias, UNAN, México D.E., p. $57-70$.
Martins L.P., Araujo-Junior, E.C., Martins A.R.P., Colins M.S., Almeida, G.C.F. \& Azevedo G.G. 2017. Butterflies of Amazon and Cerrado remnants of Maranhão, Northeast Brazil. Biota Neotrop. 17(3): e20170335 http://dx.doi. org/10.1590/1676-0611-BN-2017-0335 (last access on 27/08/2018).

Mielke O.H.H., Emery E.O. \& Pinheiro C.E.G. 2008. As borboletas Hesperiidae (Lepidoptera, Hesperioidea) do Distrito Federal, Brasil. Rev. Bras. Entomol. 52(2): 283-288.

Nery I., Carvalho N. \& Paprocki H. 2014. Checklist of butterflies (Insecta: Lepidoptera) from Serra do Intendente State Park - Minas Gerais, Brazil. Biodivers. Data J. 2: 1-23.

Nobre C.E.B., Schlindwein C. \& Mielke O.H. 2008. The butterflies (Lepidoptera: Papilionoidea and Hesperioidea) of the Catimbau National Park, Pernambuco, Brazil. Zootaxa 1751: 35-45.

Oksanen J., Blanchet F.G., Kindt R., Legendre P. Minchin P.R., O'hara R.B., Simpson G.L., Solymos P., Stevens M.H.H. \& Wagner H. 2015. Vegan: Community Ecology Package. R package version 2.3-4. Available from http://CRAN.R-project.org/package=vegan.

Oliveira-Filho A.T. \& Machado J.N.M. 1993. Composição florística de uma Floresta Semidecídua Montana, na Serra de São José, Tiradentes, Minas Gerais. Acta bot. bras. 7(2): 71-88.

Pereira G.C.N., Coelho M.S., Beirão M.V., Braga F. \& Fernandes G.W. 2017. Diversity of fruit-feeding butterflies in a mountaintop archipelago of rainforest. PLoS ONE 12: e0180007.

Pinheiro C.E.G., Malinov I.K., Emery E.O. \& Schmidt K. 2010. Endemismos e conservação de borboletas (Lepidoptera: Papilionoidea e Hesperioidea) no bioma Cerrado. In Cerrado: Conhecimento científico quantitativo como subsídio para ações de conservação (I.R. Diniz, J. Marinho-Filho, R.B. Machado \& R.B. Cavalcanti, eds.). UNB, Brasília, p. 225-238.

Pires A.C.V., Beirão M.V., Fernandes G.W., Oliveira I.F., Pereira G.C.N., Silva V.D., Mielke O.H.H. \& Duarte M. 2018. Checklist of butterflies from the rupestrian grasslands of Serra do Cipó, Minas Gerais, Brazil (Lepidoptera: Papilionoidea). SHILAP Revta. lepid. 46(181): 5-17.

R Development Core Team. 2017. R: A language and environment for statistical computing. R Foundation for Statistical Computing [Internet]. Viena, Austria: R Foundation for Statistical Computing.

Rapini A., Ribeiro P.L., Lambert S. \& Pirani J.R. 2008. A flora dos campos rupestres da Cadeia do Espinhaço. Megadiversidade 4(1-2): 15-23.

Ribeiro D.B., Williams M.R., Specht A. \& Freitas A.V.L. 2016. Vertical and temporal variability in the probability of detection of fruit-feeding butterflies and moths (Lepidoptera) in tropical forest. Aust. Entomol. 55(1):112-120.

Santos J.P., Iserhard C.A., Teixeira M.O. \& Romanowski H.P. 2011. Fruit-feeding butterflies guide of subtropical Atlantic Forest and Araucaria Moist Forest in State of Rio Grande do Sul, Brazil. Biota Neotrop. 11(3): 253-274 http:// www.biotaneotropica.org.br/v11n2/en/abstract?article+bn01311032011 (last access on 17/08/2018).

Silva A.R.M., Pontes D.V., Guimarães M.P., Oliveira M.V., Assis L.T.F. \& Uehara-Prado M. 2015. Fruit-feeding butterflies (Lepidoptera: Nymphalidae) of the Área de Proteção Especial Manancial Mutuca, Nova Lima and Species list for the Region of Belo Horizonte, Minas Gerais, Brazil. Biota Neotrop. 15(3): e20140118 http://dx.doi.org/10.1590/1676-06032015011814 (last access on 17/08/2018).

Silva J.M., Krüger C., Siewert R.R. \& Silva E.J.E. 2017. Borboletas em áreas de vegetação nativa e plantio de eucalipto no extremo sul do Brasil (Lepidoptera: Papilionoidea). SHILAP Revta. lepid. 45(177): 5-16.

Silveira F.A., Negreiros D., Barbosa N.P., Buisson E., Carmo F.F., Carstensen D.W., Conceição A.A., Cornelissen T.G., Echternacht L., Fernandes G.W., Garcia Q.S., Guerra T.J., Jacobi C.M., Lemos-Filho J.P., Stradic S.L., Morellato L.P.C., Neves F.S., Olibeira R.S., Schaefer C.E., Viana P.L. \& Lambers H. 2016. Ecology and evolution of plant diversity in the endangered campo rupestre: a neglected conservation priority. Plant Soil 403(1-2): 129-152. 
Soldati D., Silveira F.A. \& Silva A.R.M. Butterfly fauna (Lepidoptera, Papilionoidea) in a heterogeneous area between two biodiversity hotspots in Minas Gerais, Brazil. Papéis Avulsos de Zoologia 59: e20195902.

Thomas J.A. 2005. Monitoring change in the abundance and distribution of insects using butterflies and other indicator groups. Phil. Trans. R. Soc. B. 360(1454): 339-357.

Uehara-Prado M., Fernandes J.O., Bello A.M., Machado G., Santos A.J., Vazde-Mello F.Z. \& Freitas A.V.L. 2009. Selecting terrestrial arthropods as indicators of small-scale disturbance: A first approach in the Brazilian Atlantic Forest. Biol. Conserv. 142(6): 1220-1228.
Vasconcelos M.F. 2011. O que são campos rupestres e campos de altitude nos topos de montanha do leste do Brasil? Braz. J. Bot. 34(2): 241-246.

Received: $12 / 09 / 2018$

Revised: 09/04/2019

Accepted: 18/04/2019

Published online: 09/05/2019 